\title{
Service Learning in an International Context
}

\author{
J o h n A n n e t t e
}

Middlesex University, $U K$

\section{Introduction}

To what extent can higher education institutions contribute to the development of a global civil society and assist local communities in having a democratic voice in the process of globalisation? To what extent do institutions provide for their students the opportunities to develop the key skills and capabilities to understand the process of globalisation that is shaping their lives so rapidly and enable them to develop as global citizens? International service learning can provide for an education in global citizenship for its students through engaging students in global civic engagement.

Service learning is an important form of learning in higher education in the United States and the United Kingdom, and increasingly in universities internationally. Service learning is defined as an experiential learning program where students learn through engaging in service in partnership with a local community. It involves reflective learning activities which enable a student to develop key skills and capabilities, and a greater sense of civic awareness and active citizenship. The experience should be of sufficient length to enable students to benefit fully from it, and they must be challenged to be reflective and to link their learning to their college curriculum.

\section{Service Learning in the United States}

Ernest Boyer and the Carnegie Foundation for the Advancement of Teaching (Boyer, 1994 and 1996) have emphasized the role of civic 
engagement in higher education. Boyer views learning not only for academic knowledge, but also for developing student leadership. More recently, the work of the American Association of Higher Education has recognised service learning or community-based learning as an important way in which students can develop skills through work experience as well as experience an education for citizenship. Ira Harkavay at the University of Pennsylvania has been an innovator with his university/communityschool partnerships in West Philadelphia, which is the core theme of a recent collection of essays entitled Civic Responsibility and Higher Education (Ehrlich et.al., 2000). Ehrlich and his contributors discuss the variety of ways in which higher education can engage in partnership with local communities in developing civic engagement, an example of which is the organisation Campus Compact, which promotes renewal in campus/community partnerships (see the organization's website at $<$ www.compact.org $>$ ).

In the United States, since the 1960's, there has been a tradition of service learning based upon the principles of experiential education which has been supported by the National Society for Experiential Education (NSEE). Since 1971 the NSEE has been engaged in the development of the pedagogy of service learning and the promotion of research into experiential education (e.g., Eyler and Giles, 1999). More recently, the American Association for Higher Education (AAHE), in partnership with the Corporation for National and Community Service, has commissioned volumes by leading academic figures to examine the importance of service learning in higher education. What is important about the work of the NSEE and the AAHE is that it is promoting research on pedagogic practices that goes beyond anecdotal evidence and focuses on the evaluation of the learning outcomes of service learning (see, for example, the special issue of the Michigan Journal of Community Service Learning, Fall 2000).

Professor Benjamin Barber, in a number of influential articles and books, has advocated the education for active citizenship in higher education through engaging in critical thinking about politics and civil society linked to community service learning. Since the 1990's, the emphasis in the US has been on the link between citizenship education and service learning. This notion of active citizenship emphasizes not only the importance of human rights, but also stresses the significance of social responsibility, or duty, as well as democratic participation. At Rutgers University, 
Barber established the Citizenship and Service Education (CASE) program, which has become an important model for education for citizenship. An important research question which needs to be examined is what the necessary elements are for a service learning program which can build not only social capital through community service or student volunteering, but also active citizenship. There is also an increasing emphasis on the need for service learning programs to meet the needs of local community partners, which in an international context is even more of a challenge.

\section{Service Learning in the United Kingdom}

Worldwide, there are many examples of universities recognising the challenge of establishing working partnerships with local and regional communities. Community service and service learning programs are an increasingly popular response to this challenge. In some higher education systems, however, community partnerships are seen primarily in terms of economic development, cultural formation and technology transfer, and not in terms of the higher education curriculum itself. It is interesting to note that the United Kingdom organisation of university and college presidents report on Universities and Communities highlighted the role of universities in local and regional development. However, except for the appendix by John Mohan, it did not consider how university and community partnerships would impact the higher education curriculum (CVCP, 1994; and for criticisms cf. Watson and Taylor, 1998; and Annette, 1999).

In the UK, a major Royal Commission under Lord Ron Dearing was established to examine the future of British higher education. One of the main aims of higher education, according to the Dearing Report, is to contribute to a democratic, civilised and inclusive society (1997). The emphasis on civic engagement highlights the need for the higher education curriculum to prepare graduates to become active citizens and to participate not only in formal politics, but also to play a leadership role in civil society. The Dearing Report follows an increasing range of work done since the 1970's that has emphasized the importance in higher education of the development of what has been termed transferable, personal, core or key skills. The challenge for higher education, according to the Dearing Report, is to provide an academic framework that is based on the acquisi- 
tion of critical knowledge, mostly structured upon the present framework established by the academic disciplines, and which provides students with the opportunity to develop essential "key skills and capabilities." In the UK this is particularly a challenge for higher education because the new citizenship curriculum in schools following the Crick Report on Education for Citizenship and the Teaching of Democracy in Schools in 1998 resulted in the new compulsory citizenship education subject in English high schools, which strongly encourages the establishment of service learning programs (Crick, 1998; Annette, 2000).

The UK's Department for Education and Skills has supported research into work experience (Brennan and Little, 1996; Harvey, et.al., 1998; and Little, 1998), but only recently has it begun to support research into service learning. The Fund for the Development and Teaching (FDTL) projects such as the Community Based Learning and Teaching Project, based at the Universities of Birmingham and Liverpool, and the forthcoming research work on the learning outcomes of service learning by Dr. David Hall of Liverpool University and my own work at Middlesex University, are examples of this research.

In the UK the Council for Citizenship and Learning in the Community (CSV/CCLC) has been promoting and facilitating education for citizenship and service learning in higher education by working in partnership with over 200 programs in higher education institutions. The aims of this national, multidisciplinary and community-linked network is to promote service learning through university/community partnerships that it accredits or certifies, and which develops students' skills and citizenship, as well as meets community needs. Some of the partner universities are the Interchange and now Community Bridge project in Liverpool (linking Liverpool, Liverpool John Moores and Liverpool Hope Universities), the Community Exchange project in Manchester (linking UMIST, Manchester, Salford, and Manchester Metropolitan Universities), Napier University and the Edinburgh University Settlement Program, The Northern Ireland Science Shop (linking the Queens University Belfast and the University of Ulster), the Roehampton Institute MA in International Service Learning, and the Voluntary Community Service Learning Program at Middlesex University. In 2002 the British government established the new "Higher Education Active Community Fund," which has provided funding for the establishment of community service 
programs based on effective community partnerships in all English universities. This fund, however, raises the possibility that citizenship education and service learning could become an important feature of higher education in Britain by providing funding for the development of university/community partnerships.

\section{Service Learning Outside the United $S$ tates and the United Kingdom}

What is particularly striking about service learning is how it is developing internationally. It is no longer the case that it is only part of higher education in the US and the UK. Service learning in higher education can now be found, for example, in the Philippines, Singapore, Mexico, Brazil, Japan, and in Eastern and Central Europe.

In 1998, Howard Berry and Linda Chisholm began to investigate the extent to which what might be the equivalent of "service learning" can be found in higher education institutions around the world. This is the first survey of this kind, and it discovered a remarkable range of universities and colleges that offer "service-learning" internationally. It is a study which is already out of date, as the number of universities around the world which are developing service learning is growing rapidly (Berry and Chisholm, 1999). The research was informed by the outcomes of an international meeting in May 1998 at the Wingspread Conference Center, which was supported by the Ford Foundation and the Johnson Foundation. Some forty-two service learning educators from sixteen nations attended the event to report on service learning in their countries and to consider ways to further develop it internationally. The Wingspread Resolutions are printed as an appendix to the report and provide fine principles for the promotion of international service learning. The research for the report was based on a questionnaire that was sent to institutions around the world (no information is provided in the report as to the number of institutions or to their geographic spread). Sixty-four institutions of higher education in twenty-three nations responded and the details from twenty-three additional service learning programs were also included. Finally, the opinions of higher education experts from other parts of the world, who are listed in the appendix, were used in compiling the report. There is no quantitative analysis and the findings are pre- 
sented in a thematic framework. While the report strives very hard to address the issue of cross-cultural understanding by largely utilising the terms provided by the responses, this unfortunately leads to some conceptual confusion. There does not seem to be a clear distinction between programs of national and community service as distinct from service learning. There is also no clear discussion of how this service is based on effective community partnerships, how it promotes active citizenship, and what principles of service learning are used to identify service learning programs. These are important issues facing service learning not only in the US, but also internationally.

\section{International Service Learning}

In the US and the UK there are a growing number of service learning study abroad programs. Most of these are so-called "island programs" in which a group of students and a professor travel abroad and engage in a service learning project, typically with a Non-Governmental Organization (NGO) and sometimes with a local community organisation. Many of these programs involve collaboration between service learning and study abroad offices, and are taught as "action" research courses that include fieldwork involving service learning in a community.

A research literature is beginning to arise from service learning/study abroad programs. One example from the University of Portland is a service-learning program where students worked as volunteers in an orphanage in Chile. The research involved the staff engaging in a content analysis of a questionnaire for program participants (DiSpigno et al., 2001). The findings generally confirmed that the program fulfilled the needs of staff, students and local community participants. However, the study discovered a cultural misunderstanding between the students and the local community organisation participants about the goals of the local community organisation. This study raises some important questions about the cultural differences between the service learning program and the local community organisations with whom students work, pointing out the importance of identifying precisely the goals and objectives of both.

An illuminating study by Porter and Monard (2001), educational anthropologists at the University of Pittsburgh, considers how the 
Andean cultural metaphor of ayni provides an interpretative framework for analysing a field work program in Bolivia. Ayni can mean "reciprocity" or "reciprocal exchange relationships," which are more than contractual relationships. The ayllu, or neighbourhood communities, of the Andes rely on ayni as a form of interdependence for both survival and development. The ayni metaphor enabled the researchers to explore the nature of the partnership at work (my terms not theirs) in the service learning program. They used an iterative series of qualitative interpretative analyses as part of an ethnographic study integrating multiple modes of data collection. They argue that "Thinking about service-learning in terms of ayni requires a shift in both language and practice" (Porter and Monard, p.2, 2001).This research highlights the problem of cultural meaning in engaging in international service learning, which can be approached through the research techniques of cultural anthropology. Another conclusion from the Porter and Monard research is that such programs must be built on the genuine needs of all partners and that the exchange relationship must be equitable for all participants. This point also raises questions about the use of NGOs in non-Western countries and their relationship with local NGOs or local community organisations.

The development of international service learning provides key opportunities for universities in these countries to work in partnership with NGOs and community organisations for sustainable community development (Gaventa, 1998; Edwards and Gaventa, 2001). One of the key issues facing those who work in the area of international community development is how to move beyond the hype about what constitutes civil society in diverse societies. Do northern hemisphere NGOs represent the interests of locally-based NGOs or local community organisations? Two major participatory research programs which have attempted to include the "voices" of the citizens of local communities across diverse global societies are the surprisingly radical World Bank Survey of Poor Peoples (2000) and the Commonwealth Foundation study of civic participation involving 10,000 citizens in 47 countries (Knight et al., 2002). John Gaventa and his colleagues at the Institute of Development Studies at the University of Sussex, in the UK, are helping to develop participatory action research networks across global communities. The challenge of measuring either community outcomes or the promotion of assets for university/community partners in international service learning programs is 
made more difficult by the increased range of variables that would be involved in such an international analysis. Nevertheless, any analysis of international service learning will need to consider the outcomes of the university/community partnerships involved.

More recently, the British Council has supported development of a community service program at the University of Jordan in Amman which is linked to the Muslim faith and the development of civil society. In South Africa, the Community Higher Education Service Partnership Project (CHESP), which is managed by the Joint Education Trust (JET), is supported by the Ford Foundation, involves five South African Universities with pilot community partnership service learning programs. The aim of the CHESP project is "the reconstruction and development of South African civil society through the development of socially accountable models of higher education, research, community service and development" (JET, p.2, 1999; cf. MacMillan and Saddington, 2000; and Subotzky, 1999).

Which elements of international service learning programs can build not only social capital through community service or student volunteering but also active citizenship? A recent Ford Foundation Workshop on "Youth Involvement" considered the development of youth civic engagement including the activities of higher education students. While there are many impressive examples of national civic service programs involving higher education students, few of these involve service learning. For example, in Mexico the "Servicio Social" requires higher education students to render civic service, and in 1999 some 299,000 students did so. However, a recent report on the Servicio Social indicated that one key challenge is how to integrate civic service more fully with the curriculum. The report does go on to indicate that some $60 \%$ of higher education institutions now recognise civic service in some way as part of the curriculum (Ford Foundation, 2000). Underlying the report is an assumption that activities which increase social capital will lead to an increase in active citizenship. However, as the 1999 research of Eyler and Giles shows, there is a need for a more analytical framework for understanding how service learning can lead to an increase in active citizenship (Eyler and Giles, 1999).

The development of service learning in international higher education provides opportunities for students from these countries to engage in 
student exchange and service learning with students from different cultural, social, political and economic contexts. Universities can play a key role in developing networks for a global civil society and global citizen action. This will enable students to develop both an understanding of globalisation and an intercultural understanding of community development across national and regional boundaries. International service learning can, through experiential engagement and reflective learning activities, enable students to recognise "difference" while developing a sense of shared global citizenship. Many of the ethical issues raised in the excellent recent publication Globalisation and Higher Education (DEA/AUT, 1999), such as human rights and sustainable development, can be addressed by students engaged in global service learning through international partnerships between universities. Middlesex University, for example, has established an "International Service Learning Program" that provides learning opportunities for international students, exchange students and study abroad students to learn about citizenship and community development in a global context. According to Benjamin Barber, "These civic efforts-the work of citizens rather than governments, or the work of governments reacting to citizens (and not just their own)—embody a global public opinion in the making, a global civic engagement that can alone give the abstraction of international politics weight" (Barber, 2000). Service learning in international education is a means to provide just such an education for global citizenship.

\section{References}

Annette, John, and Sue Buckingham-Hatfield. Student-Community Partnerships in Higher Education. London: CSV Publications, 1999.

Annette, John. "Citizenship and Service Learning in Higher Education."

Education for Values. Eds. J.Gardner, et.al. London: Kogan Page, 1999.

---. "Citizenship Education and Experiential and Service Learning in Schools." Education for Citizenship. Eds. Roy Gardner, et.al. New York: Continuum, 2000.

---. "Global citizenship and learning in communities." The Development Education Journal 8.1 (2001).

Barber, Benjamin. A Place for Us: How to Make Society Civil and Democracy Strong. New York: Hill and Wang, 1998. 
---. A Passion for Democracy. Princeton, NJ: Princeton University Press, 1998.

---. "Globalizing Democracy.” American Prospect 11.20 (2000).

Berry, Howard, and Linda Chisholm. Service-Learning in Higher Education A round the World: an Initial Look. New York: International Partnership for Service-Learning, 1999.

Boyer, Ernest. "Creating the new American college," The Chronicle of Higher Education 9 March 1994.

---. "The Scholarship of Engagement." The Journal of Public Service and Outreach 1.1 (1996).

Brennan, John, and Brenda Little. A Review of Work Based Learning in Higher Education. London: DfEE, 1996.

CVCP. Universities and Their Communities. London: CVCP, 1994.

CVCP/ DfEE. Skills Development in Higher Education. London: CVCP, 1999. DEA/AUT. Globalisation and Higher Education. London: Association of University Teachers and Development Education Association, 1999.

DiSpigno, Anthony, et al. "Combining Volunteer Work and Study Abroad: An International Service Learning Project," NSEE Quarterly 26.4 (2001).

Edwards, Michael, and John Gaventa, eds., Global Citizen Action. London: Earthscan, 2001.

Ehrlich, Thomas, ed. Civic Responsibility and Higher Education. Washington, DC: American Council for Higher Education/Oryx Press, 2000.

Janet Eyler, and Dwight Giles, Jr. Where's the Learning in Service Leaning? San Francisco: Jossey-Bass, 1999.

Ford Foundation. Worldwide Workshop on Youth Involvement as a Strategy for Social, Economic and Democratic Development. New York: Ford Foundation, 2000.

Gaventa, John. "Crossing the great divide: Building links between NGO's and community based organisations in north and south." International Perspectives on the Third Sector. Ed. D.Lewis. London: Earthscan, 1998.

Harvey, Lee, et.al. Work Experience: Expanding Opportunities for Undergraduates. London: Centre for Research into Quality, 1998.

Howard, Jeffrey, ed. Strategic Directions for Service-Learning Research. Spec. issue of Michigan Journal of Community Service Learning Fall (2000).

Kahne, Joseph., et al. "Service-Learning and Citizenship: Directions for 
Research." Michigan Journal of Community Service Learning 8.1 (2000). Knight, Barry., et.al., Reviving Democracy: Citizens at the Heart of Governance. London: Earthscan, 2002

Little, Brenda. Developing Key Skills Through Work Placement. London: CIHE, 1998.

MacMillan, Janice, and Tony Saddington. "Service Learning Partnerships as a catalyst for higher education transformation: reflections on a South African initiative," NSEE Conference paper, 2000.

National Committee of Inquiry into Higher Education [NICHE] (UK) Dearing Report: Higher Education in the Learning Society. 1997.

National Committee of Inquiry into Higher Education [NICHE] (UK) The Crick Report: Education for Citizenship and the Teaching of Democracy in Schools. 1997.

Porter, M., and K. Monard. "Ayni in the global village: Building relationships of reciprocity through international service-learning." Michigan Journal of Community Service Learning 8.1 (2001).

Subotzky, G., "Alternatives to the entrepeneurial university: new modes of knowledge production in community service programs." Higher Education 38.4 (1999).

Watson, David, and Richard Taylor. Lifelong Learning and the University. London: Falmer Press, 1998. 